Review

\title{
Surface Engineering for Bone Implants: A Trend from Passive to Active Surfaces
}

\author{
Ruggero Bosco, Jeroen Van Den Beucken, Sander Leeuwenburgh and John Jansen * \\ Department of Biomaterials, Radboud University Nijmegen Medical Center, Nijmegen 6525, \\ The Netherlands; E-Mails: r.bosco@dent.umcn.nl (R.B.); j.vandenbeucken@dent.umcn.nl (J.V.D.B.); \\ s.leeuwenburgh@dent.umcn.nl (S.L.) \\ * Author to whom correspondence should be addressed; E-Mail: j.jansen@dent.umcn.nl; \\ Tel.: +31-0-24-361-4006; Fax: +31-0-24-361-4657.
}

Received: 15 May 2012; in revised form: 7 June 2012 / Accepted: 19 June 2012 /

Published: 2 July 2012

\begin{abstract}
The mechanical and biological properties of bone implants need to be optimal to form a quick and firm connection with the surrounding environment in load bearing applications. Bone is a connective tissue composed of an organic collagenous matrix, a fine dispersion of reinforcing inorganic (calcium phosphate) nanocrystals, and bone-forming and -degrading cells. These different components have a synergistic and hierarchical structure that renders bone tissue properties unique in terms of hardness, flexibility and regenerative capacity. Metallic and polymeric materials offer mechanical strength and/or resilience that are required to simulate bone tissue in load-bearing applications in terms of maximum load, bending and fatigue strength. Nevertheless, the interaction between devices and the surrounding tissue at the implant interface is essential for success or failure of implants. In that respect, coatings can be applied to facilitate the process of bone healing and obtain a continuous transition from living tissue to the synthetic implant. Compounds that are inspired by inorganic (e.g., hydroxyapatite crystals) or organic (e.g., collagen, extracellular matrix components, enzymes) components of bone tissue, are the most obvious candidates for application as implant coating to improve the performance of bone implants. This review provides an overview of recent trends and strategies in surface engineering that are currently investigated to improve the biological performance of bone implants in terms of functionality and biological efficacy.
\end{abstract}


Keywords: inorganic; organic; composites; plasma spray; surface modifications; bone; implants; coating techniques

\section{Introduction}

The use of medical implants has expanded dramatically during the past decades owing to increased life-expectancy, changing lifestyles and improved implant technology. Problems related to orthopedic, oral and maxillofacial disorders annually affect millions of patients that need a long-term solution to regain a high quality of life. Diseases and problems caused by damaged or diseased bone tissue represent an annual cost that now exceeds 40 billion Euro worldwide [1]. Nevertheless, the rapid increase in the number of elderly people and the corresponding growth of the world population require that tissues and organs endure longer and are also able to perform in compromised health conditions [2].

The musculoskeletal system has structural, protective and mechanical functions. Consequently, in order to develop functional replacements for diseased/malfunctioning joints or bone-anchored elements (like teeth), extensive and multidisciplinary knowledge on bone healing is required. The emergence of modern biology has provided novel insights into the biological mechanisms that are responsible for bone healing which currently facilitates the development of artificial implants that interact optimally with bone tissue [3].

The present review provides an overview of the requirements for bone implants and the approaches that are currently investigated to increase their performance by means of surface modifications. Both physical and chemical surface modifications are being discussed to transform passive inert implants into smart implant surface that actively instruct the physiological environment towards regeneration of bone tissue.

\section{Bone Implants}

\subsection{Implants: Interface between Living Tissue and Dead Matter}

Bone is a natural and highly hierarchical structured organic-inorganic composite material made of collagen fibrils hardened with interspersed hydroxyapatite (HA) nanocrystals. Bone is one of the very few human tissues that contains an inorganic phase for mechanical reinforcement.

The skeletal system is responsible for the support, movement, and protection of the internal organs. During activities such as walking and chewing, heavy loads are transferred towards bone tissue which means that artificial implants need to be load-bearing. Cycles of chewing, for example, are estimated to be of the order of $1 \times 10^{5}$ cycles a year with an average force of $700 \mathrm{~N}$ [4,5]. The mechanical properties of bone tissue are maintained through a continuous remodeling process of bone formation and resorption (bone turnover) that is regulated by "Wolff's Law":

"Bone is deposited and reinforced at areas of greatest stress" [6].

The cells which are responsible for tissue remodeling are osteoblasts (bone-forming) and osteoclasts (bone-resorbing) [3]. Once a material is introduced into bone tissue, a foreign body 
response is initiated in the surrounding tissue. In more detail, this response consists of the following phases: injury, blood-material interactions, blood clot formation, inflammatory responses, granulation tissue development, and tissue remodeling. Bone tissue can be formed directly at the implant surface of certain bone-bonding materials without the formation of surrounding fibrous tissue capsules, whereas synthetic materials are generally encapsulated upon implantation in soft tissue. During a foreign body response, the local biological environment is different from the healthy tissue since this foreign body response results into elevated concentrations of reactive oxygen species, proteolytic enzymes, fibrotic proteins, giant cells and reduced $\mathrm{pH}$ values near the implant surface. As a result, this altered environment has a strong effect on implanted materials, which means that this initial biological response should be the starting point for design of novel implant surfaces with improved functionality [7].

\subsection{Material Requirements for Load-Bearing Bone Implants}

Metals are applied as biomaterials for bone substituting applications due to their superior mechanical performances. The elastic modulus of cortical bone ranges from 10 to $20 \mathrm{GPa}[4,8,9]$, which is considerably lower compared to values of metallic biomaterials that are conventionally used for load-bearing applications such as titanium and stainless steel which exhibit elastic moduli of about $118 \mathrm{GPa}$ [10] and $206 \mathrm{GPa}$ [11], respectively. Besides elasticity, fatigue properties are also crucial for optimal performance of permanent bone implants. The strong resistance to fatigue is an additional factor which has prompted the use metals in load bearing applications.

The transmission of load between the artificial implant and host tissue is crucial to ensure anchoring of bone implants in bone tissue. Load distribution at the interface between a load-bearing bone implant and natural tissue is strongly affected by the differences in elastic modulus and mechanical strength. A mismatch in stiffness between implants and bone tissue, for example, can cause severe bone resorption due to the reduction of stress from bone tissue. This phenomenon, known as stress shielding [4], can have severe consequences that compromise the success of bone implants. A material that can achieve a strong fixation between bone tissue and the implant surface can transfer the load and the stress from the implant to the surrounding bone tissue, thereby ensuring sufficient bone density and strength [12].

In addition to its mechanical performance, synthetic materials that are implanted in bone tissue need to be non-toxic, non-immunogenic, non-thrombogenic, and non-carcinogenic [13]. In that respect, titanium and its alloys have become preferred materials due to their high specific strength, low elastic modulus which matches with the elastic modulus of bone tissue, and most of all, their capacity to form a thin but very stable oxide layer (i.e., passivation) on the surface which is responsible for its inertness [14].

Although bio-inertness can be considered as a beneficial property for load-bearing implant surfaces, the advent of regenerative medicine has resulted into a paradigm shift with respect to the concept of biocompatibility. As a result, the importance of surface modifications has increased considerably. In 1987, biocompatibility was defined as "the ability of a material to perform with an appropriate host response in a specific situation" [13]. During the following two decades, however, the concept of biocompatibility has shifted continuously resulting into changing design criteria for novel implant materials. As a consequence, surface properties of implants have gained importance since artificial 
implants are exposed to the surrounding tissue at the material surface. As a result, implants are currently designed from a bio-inspired rather than a technologically inspired perspective

\subsection{From Passive to Active Bone Implant Surfaces}

As described above, modifications of bone implant surfaces have received increasing research interest in order to orchestrate the physiological healing process and obtain biologically active materials that provide biological cues towards tissue regeneration. The ability to target and trigger specific responses and recruit the correct type of cells or stimulate them to perform optimally requires additional functionality of the bone implant surface. The deposition of coatings allows modifying the surface of a material to evoke preferred biological responses, including the reduction of non-specific protein adsorption and immobilization of compounds that encourage specific interactions with cells. Such coatings can be made of materials that degrade in a controllable manner over time without compromising the bulk properties of the device, thereby obtaining a modulated response that transforms a material from passive to active. Recently, Williams stressed the bioactive role of materials as described above by defining biocompatibility as $[13,15]$ "the ability of a biomaterial to perform its desired function with respect to a medical therapy, without eliciting any undesirable local or systemic effects in the recipient or beneficiary of that therapy, but generating the most appropriate beneficial cellular or tissue response to that specific situation, and optimizing the clinically relevant performance of that therapy".

In the current review, the term "passive" refers to implants that are not chemically or biologically reactive and present rather inert surfaces to the surrounding tissues, whereas the term "active" refers to implants that have been modified to deliberately interfere with the physiological environment by providing biological cues that trigger specific responses.

\subsection{Surface Modifications for Bone Implants}

Surfaces of bone implants represent the site of interaction with the surrounding living tissue and are therefore crucial to enhance the biological performance of implants [16,17]. Surface engineering aims to design implants of improved biological performance which are able to modulate and control the response of living tissue. Generally, surface engineering includes modification of topographical (i.e., roughness) and chemical (i.e., coating) characteristics of a medical device. Topographical modifications of titanium and its alloys were aimed at increasing the roughness of implant surfaces, thus increasing the surface area of implants compared to larger smooth surfaces. The increased surface area increases cell attachment and augments the biomechanical interlocking between bone tissue and the implant. To this end, several techniques have been developed, including grit-blasting and acid etching. Grit-blasting is obtained by bombardment of implant surfaces by means of silica (also known as sand-blasting), hydroxyapatite, alumina or $\mathrm{TiO}_{2}$ particles. Acid-etching treatments are generally performed using hydrofluoric, nitric, or sulphuric acid. A detailed analysis of topographical modification of implants and its relevance for commercial applications has been performed by Dohan Ehrenfest et al. [18]. Recently, the emergence of nanotechnology has expanded the scope of topographical modifications from the micro- to nanoscale, thereby affecting cells, biomolecules and ions at the nanoscale. Nanotechnology is the field that focuses on synthesis, characterization and 
application of materials with at least one dimension sized between 1 and $100 \mathrm{~nm}$. Recently, this nanoscale dimension has received increasing interest in the field of surface engineering, e.g., by developing coatings of thickness below $100 \mathrm{~nm}$ or using nanoparticles or nanocrystals with dimensions smaller than $100 \mathrm{~nm}$ as components for nanostructured coatings [19].

Surface modifications based on the deposition of coatings retain the mechanical properties of titanium while the functionality of the implant surface can be upgraded by application of (bio)chemical compounds that act as cues towards improved bone regeneration. Upon successful immobilization of these compounds onto implant surfaces, the substrate is responsible for the load-bearing function of the implant whereas the coating should facilitate optimal integration into the surrounding tissues.

\section{Surface Engineering: Coating Deposition}

\subsection{Biological Activity of Bone Implant Coatings}

The biological response to implanted bone implants is time-dependent and should ultimately result into complete integration of the artificial implant within the native bone tissue. The initial inflammatory response that follows implant installation determines subsequent remodeling phases in the process of bone healing that lead to transfer of mechanical forces and the high degree of organization of functional bone tissue [20]. Biocompatibility and osteoconductivity of the implant are generally recognized as main success factors for satisfactory long-term performance endosseous implants [21].

Every bone implant is recognized by human tissues as a foreign body $[13,22,23]$. For this reason the main aim of coating development until two decades ago was to avoid or limit this foreign body response since an excessive foreign body response creates an intermediate layer of collagenous fibrous tissue in between the material surface and the hosting tissue [22,23]. This fibrous capsule will ultimately result into loss of implant function and ultimately implant loosening. Coatings can be applied onto bone implants to avoid soft tissue formation and create a strongly integrated and interlocked transition between tissue and the implant surface, a phenomenon that is called osteointegration. According to the European Society of Biomaterials, during the consensus conference of 1987, a material can be defined bioactive if it is "one which has been designed to induce specific biological activity". For materials implanted in bone tissue, bioactive materials correspond to implants that induce a direct bond between the implant surface and the surrounding bone tissue.

Summarizing, the primary aim of engineering bone implant surfaces is to positively modulate the interfacial response between the implant and host tissue. For this purpose, numerous surface engineering methods have been introduced in the last four decades to change surface topography and chemistry of endosseous dental implant. Junker et al. has systematically reviewed the efficacy of a wide variety of surface modifications including roughening of dental implants as well as applications of inorganic (calcium phosphate) or organic (adhesion peptides, growth factors) coatings. An overview of the most extensively used topography modifications of commercially available dental implants is reported in Table 1. The following sections will discuss current trends in surface engineering based on inorganic, organic and composite coatings. 
Table 1. Overview of commercially available surface modifications (topography) for dental implants.

\begin{tabular}{ll}
\hline Name & Description \\
\hline $\begin{array}{l}\text { OsseoSpeed (Astra Tech AB, } \\
\text { Mölndal, Sweden) }\end{array}$ & $\begin{array}{l}\text { Titanium oxide blasting followed by chemical modification of the } \\
\text { surface by hydrofluoric acid treatment } \\
\text { SLActive (ITI; Institute Straumann, } \\
\text { Coarse grit-blasting with } 0.25-0.5 \mathrm{~mm} \text { aluminum oxide grit at } 5 \text { bar } \\
\text { followed by acid etching }\end{array}$ \\
$\begin{array}{l}\text { TiUnite (Nobel Biocare Holding } \\
\text { AG, Zürich, Switzerland) }\end{array}$ & Electrochemical anodization process \\
$\begin{array}{l}\text { Nanotite (3i Implant Innovations, } \\
\text { Palm Beach Gardens, FL, USA) }\end{array}$ & Sol-gel deposition \\
$\begin{array}{l}\text { Friadent plus (Dentsply Friadent, } \\
\text { Mannheim, Germany) }\end{array}$ & $\begin{array}{l}\text { large grit blasting (354-500 } \mu \mathrm{m} \text { ) and acid etching in hydrochloric } \\
\text { assean (intra-Lock, Boca-Raton, },\end{array}$ \\
FL, USA) & is a grit-blasted/acid-etched/calcium phosphate impregnated surface \\
\hline
\end{tabular}

\subsection{Trends in Material for Inorganic Coatings on Bone Implants}

In bone tissue, the inorganic phase is mainly composed of carbonate-rich hydroxyapatite. Consequently, hydroxyapatite ceramics have always been an obvious candidate for deposition as coating onto bone implant surfaces. These hydroxyapatite coatings were shown to be bioactive and stimulate the formation of new bone tissue in numerous pre-clinical and clinical studies [24-28]. Chemical parameters such as the $\mathrm{Ca} / \mathrm{P}$ ratio, phase composition and crystal structure have been evaluated and tested extensively to optimize the performance of $\mathrm{CaP}$ coatings. HA coatings showed a persistent significant improvement of the osteoconductivity of metallic implants [29-35].

During the past two decades, recent trends in research on calcium phosphate (CaP) coatings mainly focused on modification of its chemical structure and addition of ionic dopants. Currently, several types of CaP-based coatings have been explored such as pure HA [36-44], Si-containing HA (Si-HA) [31,40,45-52], Sr-doped HA [53-56], Mg-substituted HA [47], bisphosphonate and HA [55,57], carbonated HA [32,47,58], fluorinated HA [44,59-61] and antibacterial Ag-containing HA (Ag-HA) [62-67].

\subsection{Trends in Material for Organic Coatings on Bone Implants}

Over the past two decades, organic compounds derived from the extracellular matrix (ECM) of bone issue are increasingly considered as source of inspiration for bioinspired design of organic bone implant coatings [68].

Different approaches can be used to upgrade a bone implant from a passive medical device to an instructive implant that can solicit a desired tissue response [69-73] using organic biomolecules. Organic surface modifications that are currently investigated involve immobilization of among others structural proteins, signaling molecules, enzymes or peptides onto biomaterial surfaces to target cell response at the tissue-implant interface [74,75].

A widely investigated approach aims at improving the adhesion of cells onto bone implant surfaces. ECM biomolecules such as fibronectin, vitronectin, type I collagen, osteopontin, and bone 
sialoprotein [76] have been successfully immobilized onto bone implants. These proteins exerted biological effects upon immobilization onto surfaces, but the tendency of proteins to fold upon adsorption to an implant surface remains problematic and decreases the efficacy of immobilized proteins. However, short peptide sequences derived from entire proteins can overcome this problem [77]. Surface-immobilized peptide sequences can recruit or trigger specific cellular interactions $[77,78]$. The peptide sequence that has been investigated most extensively so far is the Arg-Gly-Asp (RGD) peptide sequence which is the predominant binding site for cells via integrin receptors RGD sequence [79,80], but various other peptide sequences have been used similarly onto implanted materials [81-84].

Alternatively, osteotropic biomolecules such as growth factors (GFs) can be immobilized onto implant surfaces. Several GFs, including bone morphogenetic protein (BMP), transforming growth factor-beta (TGF- $\beta$ ), fibroblast growth factor (FGF), platelet-derived growth factor (PDGF), and insulin-like growth factor (IGF), have been shown to stimulate formation of bone tissue around implants upon immobilization onto their surface. Most emphasis, however, has been put on the immobilization of members of the TGF- $\beta$ superfamily such as BMP-2, BMP-7 and TGF- $\beta 1$, which have shown promising results in enhancing bone formation around bone implants [85-87].

Besides targeting cellular behavior directly, organic biomolecules such as collagen can also improve mechanical properties of surface coatings while biomolecules such as osteopontin, osteonectin, bone sialoprotein, osteocalcin, or alkaline phosphatase have been investigated as initiators of mineralization by deposition of calcium phosphate onto implant surfaces. For example, immobilized alkaline phosphatase was shown to induce deposition of apatitic mineralization layers in vitro and new bone formation in vivo $[68,88]$.

\subsection{Trends in Materials for Composite and Combined Coatings on Bone Implants}

Since bone is a composite tissue, deposition of composite coatings consisting of inorganic and organic constituents is an obvious next step towards design of implant coatings with improved bioactivity and efficacy.

For example, composite coatings composed of collagen and $\mathrm{CaP}$ minerals could combine the benefits of the mineral phase (in terms of osteoconduction) and the collagenous matrix (in terms of abundance of RGD-sequences) to affect cellular adhesion, subsequent proliferation, and differentiation phases [89,90]. In addition to the biological effects of collagen [91], CaP-collagen composite coatings showed an improved retention of CaP crystals onto implant surfaces [92,93].

Also growth factors have been co-deposited with calcium phosphate or collagen coatings onto implant surfaces [87,94-97]. In fact, GFs immobilized on titanium implants pre-coated with collagen showed increased osteogenic properties compared to GFs bound to untreated titanium surfaces [98,99]. This may be due to a sustained delivery profile or a higher stability of the growth factor $[94,100,101]$.

Infections during or after surgery still remain a big threat that can compromise the short- and long-term stability of orthopedic implants [102,103]. Therefore, antibiotics have also been loaded into $\mathrm{CaP}$ coatings onto titanium implants [104]. The coated antibiotic-HA-composite exhibited a reduced infection rate compared with $\mathrm{CaP}$ coatings in vivo [105]. In order to reduce the risk of antibiotic resistance also non-antibiotic organic compounds with antimicrobial activity like chlorhexidine, 
chloroxylenol, and poly(hexamethylenebiguanide) [106-112] have been investigated as potential alternatives. These organic molecules are commonly used for their broad spectrum of antimicrobial action and lower risk of drug resistance.

Composite coatings can also be prepared by incorporating antimicrobial elements such as silver ions into organic or inorganic coatings since bacterial resistance against silver is minimal [113].

Finally, bone implants are often applied in patients of compromised health. Post-menopausal osteoporosis, for example, reduces bone density resulting into higher prevalence of bone fractures. The use of a local active compound for the prevention or reduction of these osteoporotic fractures could improve the efficacy and fixation of bone implants into osteoporotic bone. Bisphosphonates (BPs) are a group of synthetic drugs with a structural backbone similar to inorganic pyrophosphate with a general structure of $\mathrm{PO}_{3}-\mathrm{C}-\mathrm{PO}_{3}$. BPs have been used, for long times, for the treatment of skeletal metabolism disorders such as osteoporosis, Paget's disease, tumor-associated osteolysis and hypercalcemia [114-116]. BPs act by reducing osteoclasts (bone resorbing cells) activity but systemic delivery of BPs by oral administration or intravenous injection is associated with serious side-effects [117,118]. The affinity of BPs for HA has been used to develop new CaP-BP composite coating systems for the controlled release of BP from bone implants [119-121]. The reduced activity of bone resorbing cells induced an improved mechanical interlocking of the implant with the hosting bone tissue and correspondingly a faster recovery from surgery [122].

\section{Coating Techniques}

In order to improve surfaces properties, innovative coating compounds only are not sufficient. Techniques and technology used to deposit these substrates onto implants surfaces have witnessed a constant evolution during the past decades. Calcium phosphate are the largest group of materials used for coating deposition, for which several types of deposition techniques have been investigated including dip and immersion coating, electrophoretic deposition, laser deposition, thermal spraying (including plasma spraying and high-velocity oxy-fuel combustion spraying), biomimetic deposition and sol-gel deposition [123]. Characteristics of several commonly used coating techniques including their advantages, limitations and precursors used are summarized in Table 2.

\subsection{Dry Deposition Techniques}

Among all the coating techniques that have been investigated for deposition of $\mathrm{CaP}$ coatings, physical coating techniques are the ones that most often reached the commercial market. These physical coating techniques, such as plasma-spraying, radio frequency magnetron sputtering, pulsed laser deposition (PLD) and ion beam assisted deposition (IBAD) have been used to deposit several types of CaPs. The most widespread method to deposit CaP coatings onto implants is the plasma-spraying technique mainly due to its high deposition rate and the possibility to cover large areas. 
Table 2. Overview of characteristics of coating techniques.

\begin{tabular}{|c|c|c|c|c|}
\hline Technique & $\begin{array}{l}\text { Coating } \\
\text { thickness }\end{array}$ & Advantage & Disadvantage & Precursor materials \\
\hline Plasma spraying & $50-250 \mu \mathrm{m}$ & High deposition rates & $\begin{array}{l}\text { Non-uniform coating crystalinity; line } \\
\text { of sight technique }\end{array}$ & $\begin{array}{l}\text { HA }[36,124-128], \text { Si-HA }[40,49] \text { and antibacterial } \\
\text { Ag- HA composite coatings }[66,67,129]\end{array}$ \\
\hline RF magnetron sputtering & $0.5-5 \mu \mathrm{m}$ & $\begin{array}{l}\text { Uniform and dense coating; } \\
\text { strong adhesion }\end{array}$ & $\begin{array}{l}\text { Line of sight technique; time } \\
\text { consuming; low deposition rates }\end{array}$ & $\begin{array}{l}\mathrm{HA}[43] \text {, Si-HA [48,52], carbonated HA [32], and } \\
\mathrm{Zn}, \mathrm{Mg} \text {, and Al-doped CaPs [130] }\end{array}$ \\
\hline Plasma spraying & $50-250 \mu \mathrm{m}$ & High deposition rates & $\begin{array}{l}\text { Non-uniform coating crystalinity; line } \\
\text { of sight technique }\end{array}$ & $\begin{array}{l}\text { HA }[36,124-128], \text { Si-HA }[40,49] \text { and antibacterial } \\
\text { Ag-HA composite coatings }[66,67,129]\end{array}$ \\
\hline Pulsed laser deposition & $0.05-5 \mu \mathrm{m}$ & $\begin{array}{l}\text { Control over coating chemistry } \\
\text { and morphology }\end{array}$ & Line of sight technique & $\begin{array}{l}\text { HA resistant to dissolution in SBF [29], Ag-HA } \\
{[131,132], \text { HA [133-140] and fluorinated HA [60] }} \\
\text { alendronate-doped HA [57] }\end{array}$ \\
\hline $\begin{array}{l}\text { Ion beam dynamic mixing } \\
\text { deposition }\end{array}$ & $0.05-1 \mu \mathrm{m}$ & High adhesive strength & $\begin{array}{l}\text { Line of sight technique; requires high } \\
\text { sintering temperatures }\end{array}$ & $\mathrm{CaP}$ coatings [141-147] \\
\hline $\begin{array}{l}\text { Ion beam assisted } \\
\text { deposition }\end{array}$ & $0.02-10 \mu \mathrm{m}$ & increased tensile bond strength & Line of sight technique; & $\mathrm{CaP}[31,148-150]$ \\
\hline Biomimetic deposition & $<30 \mu \mathrm{m}$ & $\begin{array}{l}\text { Coating of complex geometries; } \\
\text { co-deposition of biomolecules }\end{array}$ & $\begin{array}{l}\text { Time consuming; requires controlled } \\
\mathrm{pH}\end{array}$ & $\begin{array}{l}\text { osteocalcin [151], fibronectin [152] and } \\
\text { poly(L-lysine) [153]. BMP-2 incorporated into } \\
\text { biomimetic CaP coatings }[154,155] \text {. }\end{array}$ \\
\hline Sol-gel deposition & $<1 \mu \mathrm{m}$ & $\begin{array}{l}\text { Coating of complex geometries; } \\
\text { low processing temperature }\end{array}$ & $\begin{array}{l}\text { Requires controlled atmosphere } \\
\text { processing; expensive raw materials }\end{array}$ & $\begin{array}{l}\text { aluminosilicate [156], fluoridated hydroxyapatite, } \\
\text { [157] Si-substituted hydroxyapatite [158], and } \\
\text { bioglass [159-161] }\end{array}$ \\
\hline Electrophoretic deposition & $0.1-2 \mathrm{~mm}$ & $\begin{array}{l}\text { Uniform coating; coating of } \\
\text { complex geometries; high } \\
\text { deposition rates }\end{array}$ & $\begin{array}{l}\text { Difficult to produce crack-free } \\
\text { coatings; low adhesive strength }\end{array}$ & $\begin{array}{l}\text { CaP-chitosan composite coatings successfully } \\
\text { combined with } \mathrm{CaSiO}_{3} \text {, heparin, and silica } \\
{[162-164]}\end{array}$ \\
\hline Electrospray deposition & $0.1-5 \mu \mathrm{m}$ & $\begin{array}{l}\text { Co-deposition of biomolecules; } \\
\text { control over coating } \\
\text { composition and morphology }\end{array}$ & $\begin{array}{l}\text { Low mechanical strength; Line of } \\
\text { sight technique }\end{array}$ & $\begin{array}{l}\text { HA [165,166],Nano HA [167], ALP [168], } \\
\text { biomolecules-HA composite [88] collagen [169] }\end{array}$ \\
\hline
\end{tabular}


The plasma-spraying (PS) technique involves the introduction of precursor materials (feedstock)into the hot plasma jet (Figure 1) generated by a plasma torch [31,170], at atmospheric pressure (Atmospheric Plasma Spraying, APS), under vacuum (Vacuum Plasma Spraying, VPS) or under reduced pressure (Low Pressure Plasma Spraying, LPS) [171-179]. As a consequence, upon impingement of feedstock powders particles onto the implant surface, an adherent coating is formed due to partial or complete melting of the powder particles.

Figure 1. Schematic representation of a Radio Frequency (RF) plasma torch.

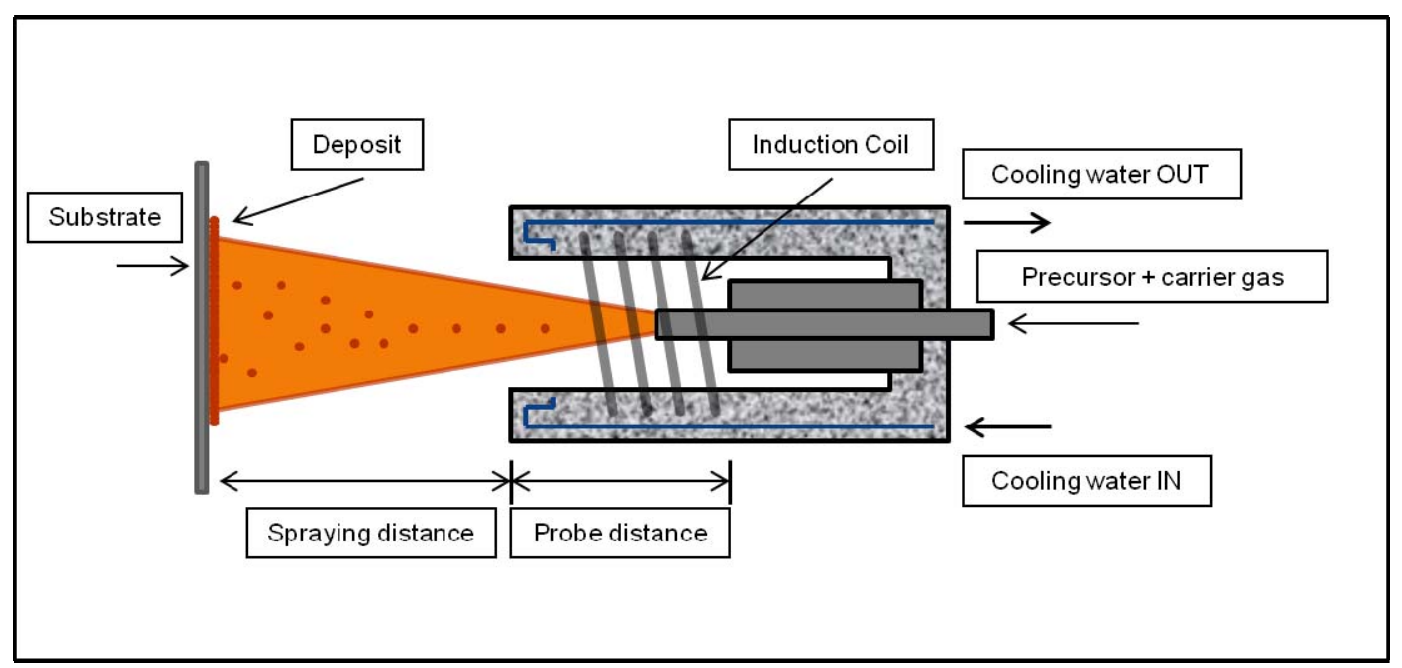

Another physical technique that is often used to deposit strongly adherent HA onto implants is Radio Frequency (RF) magnetron sputtering (Figure 2) [180-184]. Sputtering is a process whereby atoms or molecules of some materials are ejected in a vacuum chamber, becoming precursors for coating, due to bombardment with high-energy ions [31,185].

Figure 2. Schematic representation of RF magnetron sputtering.

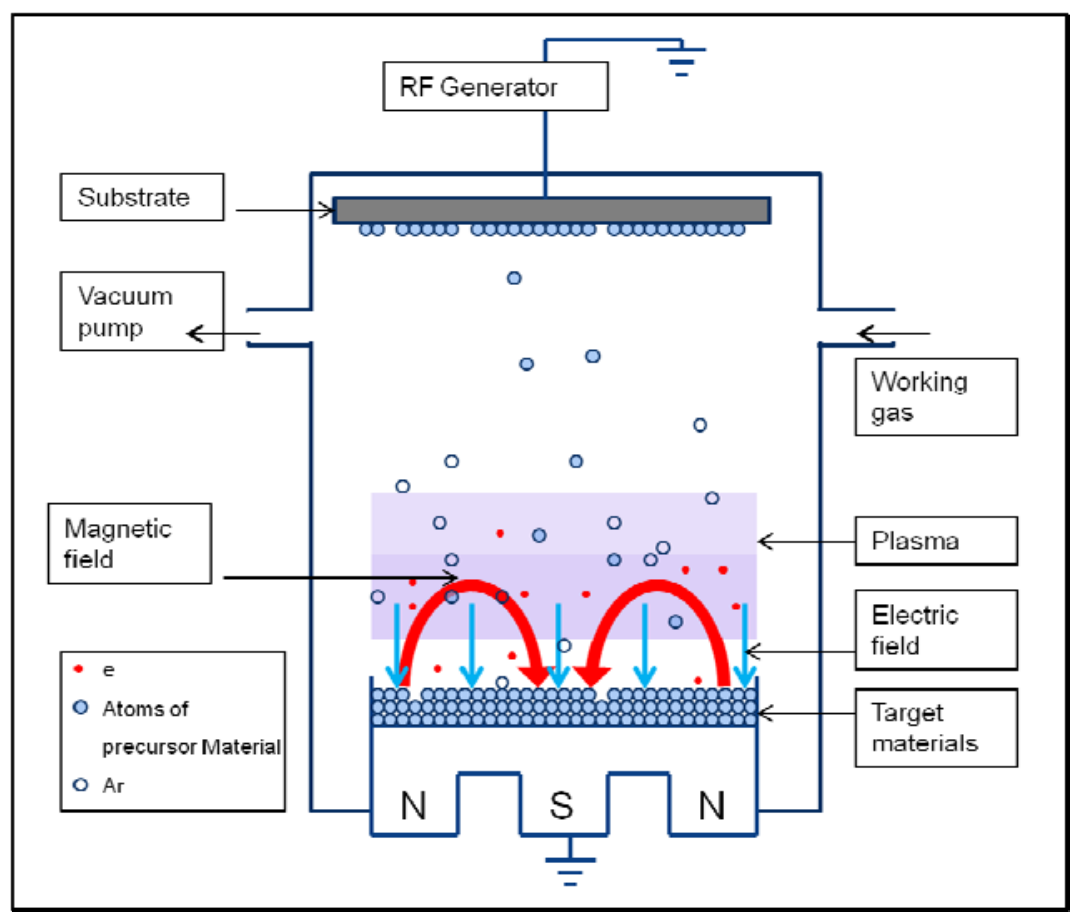


Pulsed laser deposition (PLD) is a physical vapor deposition technique that was first described by Cotell [186] to deposit thin films of CaP [55,132,138,187-191]. The PLD system (Figure 3) is typically composed of a $\mathrm{KrF}$ laser source, an ultrahigh vacuum deposition chamber equipped with a rotating target and a fixed substrate holder plus pumping systems. The PLD process involves the irradiation of a solid target by a focused pulsed laser and this interaction creates compounds such as $\mathrm{Ca}_{4} \mathrm{P}_{2} \mathrm{O}_{9}, \mathrm{Ca}_{3}\left(\mathrm{PO}_{4}\right)_{2}, \mathrm{CaO}, \mathrm{P}_{2} \mathrm{O}_{5}$, and $\mathrm{H}_{2} \mathrm{O}$ [29]. This high energy plasma cloud is composed of electrons, atoms, ions, molecules, molecular clusters and, in some cases, droplets and target fragments. This plasma cloud expands, either in vacuum or in a gaseous environment, and deposits on a substrate, typically with a temperature in the range of $350-600{ }^{\circ} \mathrm{C}$, producing a thin adherent film onto the target [192]. An alternative set-up called matrix assisted pulsed laser evaporation (MAPLE) was developed for delicate and accurate deposition of both organic and inorganic materials [133].

Figure 3. Schematic representation of the pulsed laser deposition (PLD) coating system.

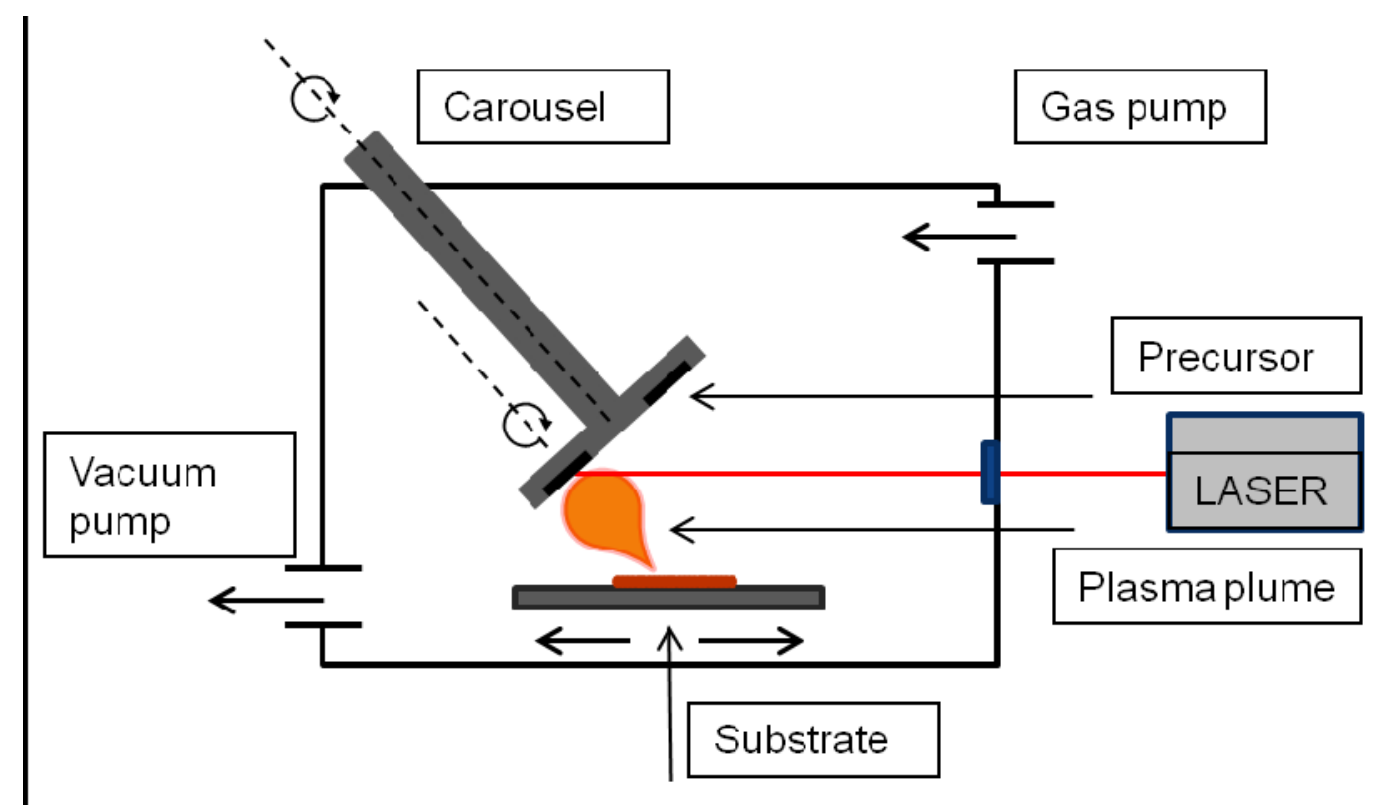

Ion beam assisted deposition (IBAD) is a vacuum technique that has also been used to deposit very thin ceramic coating layers on metals, polymers or ceramics. A typical IBAD system consists of two main elements: electron or ion bombarded precursor materials that vaporize forming an elemental cloud that covers the surface of a substrate [31,148-150] as well as an ion gun that irradiates the substrate with highly energetic gas ions that can be inert like $\mathrm{Ar}^{+}$or reactive like $\mathrm{O}^{2+}$ to induce adhesion of the precursors from the above-mentioned elemental cloud [149].

All these physical deposition techniques, however, are highly energetic to achieve a strong fixation of the coating on the surface. This energy (plasma, laser or ions bombardment) involves high temperature that can reach, in some cases, up to $2000{ }^{\circ} \mathrm{C}[193,194]$. Increased temperature during deposition facilitates a firm fixation of the coating onto the surface but it limits the selection for materials that can be coated. Organic materials and biomolecules cannot be deposited using these physical techniques and crystallinity of precursor phases are affected by the thermal process which impedes deposition of biologically relevant $\mathrm{CaPs}$ such as carbonate-substituted apatites. 


\subsection{Wet Deposition Techniques}

Wet chemical deposition methods such as biomimetic and sol-gel are alternatives to physical deposition techniques which allow for preservation of biomolecules activity. These techniques have strong advantages related to their simple experimental setup, mild chemical preparation conditions and the possibility to coat implants with a complex three-dimensional geometry (such as porous implants). Such implants cannot be coated using physical coating techniques due to their line-of-sight characteristics. In a recent review by Nijhuis et al. [75], an overview is given of current trends in wet chemical deposition of biomedical coatings for bone substitution.

The biomimetic deposition method was introduced for the first time by Kokubo et al. in 1990 and is formed under physiological conditions $\left(37^{\circ} \mathrm{C}, \mathrm{pH} 7.4, \mathrm{p}\left(\mathrm{CO}_{2}\right)=0.05\right.$ atmosphere and appropriate electrolyte concentrations) [195]. The system involves simple immersion of (pretreated) Ti substrates into a so-called simulated body fluid (SBF) to obtain deposition of a biologically active bone-like $\mathrm{CaP}$ layer formed onto the surface of the substrates.

The sol-gel technique is based on colloidal suspensions of solid particles (1-500 nm in size) in a liquid solution (a sol). The sol can be applied onto the substrate via different methods like spin-coating, spraying, or dip-coating. The coating, still in gel form, is put on the target surface and after drying only the precursor materials, through the sol-gel transition, are left as a thin layer [196,197]

\subsection{Electrochemical Deposition Techniques}

In order to combine the advantage of physical deposition (in terms of quantity control) and wet chemical deposition (non-aggressive setting) electrochemical deposition methods have been advocated. These types of coating depositions can be performed at ambient temperature and pressure provided that precursors are particles or molecules that carry an electrical charge or that can be dispersed in electrolytic solutions. The substrates, onto which the coating is applied, also need to be conductive.

Electrophoretic deposition, for instance, is a technique based on migration of precursor particles suspended in liquid towards substrate surfaces under the influence of an externally applied electrical field. The medium used for electrophoretic deposition is made of organic solvents such as isopropanol or ethanol $[198,199]$. This technique is a submersion method and so it allows for coating of, e.g., porous implants.

Another promising electrochemical coating system is the electrospray deposition (ESD) technique. Using this technology solutions or suspensions containing precursor materials are sprayed onto substrates under the influence of a high electrical field that creates an aerosol of similarly charged micron-sized droplets [200,201]. ESD allows for a strong control over physicochemical coating properties such as thickness or chemical composition.

\subsection{Clinical Performance}

Over the past two decades, the application of treatments such as gritblasting and acid etching has become widely accepted as routine topographical treatment for oral implants, as evidenced by numerous commercial implant systems that are being marketed after, e.g., a combination of 
gritblasting and acid etching. An overview of surface modification of oral implants that are commercially available is shown in Table 1.

Regarding the application of additional coatings it should be stressed that despite extensive research efforts only a limited amount of techniques have made it to clinical trials and commercialization (mainly PS, RF magnetron sputtering and IBAD), whereas most of the other techniques (such as biomimetic deposition, electrospray deposition, etc.) are still in the pre-clinical phase. In most cases, adhesion, cost-effectiveness and high costs related to industrial upscaling were the determining factors that limited widespread use and market penetration of various novel surface engineering techniques so far.

\section{Summary and Future Perspectives}

Since the application of plasma-sprayed hydroxyapatite coatings onto metallic bone implants in the 1980s, the concept of bone implant coatings has shifted from passive protecting thin films to active and instructive immobilized layers. Nowadays, a plethora of coating techniques is being investigated to actively orchestrate a desired biological response at the interface between artificial implants and the surrounding living tissue. In view of the aging population and changing lifestyle, surgeons will be confronted with an increasing number of patients of compromised health that need implants of higher efficacy than currently available.

To this end, bone implant surfaces will be increasingly enriched with biomolecules to accelerate the bone healing process. For this purpose, a wide variety of biomolecules such as growth factors, bioactive proteins, enzymes, and non-viral genes (DNAs, RNAs) is currently being evaluated pre-clinically.

For optimal therapeutic efficacy, the fate of these biomolecules needs to be controlled, i.e. efficient immobilization strategies need to be developed for covalent or non-covalent immobilization.

\section{Acknowledgments}

This research forms part of the Project P2.04 BONE-IP of the research program of the BioMedical Materials institute, co-funded by the Dutch Ministry of Economic Affairs Agriculture and Innovation.

\section{References}

1. Zethraeus, N.; Borgström, F.; Ström, O.; Kanis, J.; Jönsson, B. Cost-effectiveness of the treatment and prevention of osteoporosis-A review of the literature and a reference model. Osteoporos. Int. 2007, 18, 9-23.

2. Barrère, F.; Mahmood, T.A.; de Groot, K.; van Blitterswijk, C.A. Advanced biomaterials for skeletal tissue regeneration: Instructive and smart functions. Mater. Sci. Eng. Rep. 2008, 59, $38-71$.

3. Scholz, M.S.; Blanchfield, J.P.; Bloom, L.D.; Coburn, B.H.; Elkington, M.; Fuller, J.D.; Gilbert, M.E.; Muflahi, S.A.; Pernice, M.F.; Rae, S.I.; et al. The use of composite materials in modern orthopaedic medicine and prosthetic devices: A review. Compos. Sci. Technol. 2011, 71, 1791-1803.

4. Ramakrishna, S.; Mayer, J.; Wintermantel, E.; Leong, K.W. Biomedical applications of polymer-composite materials: A review. Compos. Sci. Technol. 2001, 61, 1189-1224. 
5. Flanagan, D.; Ilies, H.; McCullough, P.; McQuoid, S. Measurement of the fatigue life of mini dental implants: A pilot study. J. Oral Implantol. 2008, 34, 7-11.

6. Ahn, A.C.; Grodzinsky, A.J. Relevance of collagen piezoelectricity to "Wolff's Law": A critical review. Med. Eng. Phys. 2009, 31, 733-741.

7. Anderson, J.M.; Rodriguez, A.; Chang, D.T. Foreign body reaction to biomaterials. Semin. Immunol. 2008, 20, 86-100.

8. Turner, C.H.; Rho, J.; Takano, Y.; Tsui, T.Y.; Pharr, G.M. The elastic properties of trabecular and cortical bone tissues are similar: Results from two microscopic measurement techniques. J. Biomech. 1999, 32, 437-441.

9. Stephani, G.; Quadbeck, P.; Andersen, O. New multifunctional lightweight materials based on cellular metals-Manufacturing, properties and applications. In Proceedings of International Conference on Advanced Structural and Functional Materials Design, Osaka, Japan, 10-12 November 2008; doi:10.1088/1742-6596/165/1/012061.

10. Matsuno, H.; Yokoyama, A.; Watari, F.; Uo, M.; Kawasaki, T. Biocompatibility and osteogenesis of refractory metal implants, titanium, hafnium, niobium, tantalum and rhenium. Biomaterials 2001, 22, 1253-1262.

11. Mitsuo, N. Mechanical properties of biomedical titanium alloys. Mater. Sci. Eng. 1998, 243, 231-236.

12. Frost, H.M. The Utah paradigm of skeletal physiology: An overview of its insights for bone, cartilage and collagenous tissue organs. J. Bone Miner. Metab. 2000, 18, 305-316.

13. Williams, D.F. On the mechanisms of biocompatibility. Biomaterials 2008, 29, 2941-2953.

14. Tengvall, P.; Lunstrom, I. Physico-chemical considerations of titanium as a biomaterial. Clin. Mater. 1992, 9, 115-134.

15. John, C.W. Predicting clinical biological responses to dental materials. Dent. Mater. 2012, 28, 23-40.

16. Sun, L.; Berndt, C.C.; Gross, K.A.; Kucuk, A. Material fundamentals and clinical performance of plasma-sprayed hydroxyapatite coatings: A review. J. Biomed. Mater. Res. 2001, 58, 570-592.

17. Moura, C.C.G.; Souza, M.A.; Dechichi, P.; Zanetta-Barbosa, D.; Teixeira, C.C.; Coelho, P.G. The effect of a nanothickness coating on rough titanium substrate in the osteogenic properties of human bone cells. J. Biomed. Mater. Res. 2010, 94, 103-111.

18. Dohan Ehrenfest, D.M.; Coelho, P.G.; Kang, B.-S.; Sul, Y.-T.; Albrektsson, T. Classification of osseointegrated implant surfaces: Materials, chemistry and topography. Trends Biotechnol. 2010, 28, 198-206.

19. Mendonça, G.; Mendonça, D.B.S.; Aragço, F.J.L.; Cooper, L.F. Advancing dental implant surface technology-From micron- to nanotopography. Biomaterials 2008, 29, 3822-3835.

20. Lemons, J.E. Biomaterials, biomechanics, tissue healing, and immediate-function dental implants. J. Oral Implantol. 2004, 30, 318-324.

21. Albrektsson, T.; Wennerberg, A. Oral implant surfaces: Part 1-Review focusing on topographic and chemical properties of different surfaces and in vivo responses to them. Int. J. Prosthodont. 2004, 17, 536-543.

22. Ratner, B.D.; Bryant, S.J. Biomaterials: Where we have been and where we are going. Annu. Rev. Biomed. Eng. 2004, 6, 41-75. 
23. Anderson, J.M. Biological responses to materials. Ann. Rev. Mater. Sci. 2001, 31, 81-110.

24. Yang, Y.; Kim, K.H.; Ong, J.L. A review on calcium phosphate coatings produced using a sputtering process an alternative to plasma spraying. Biomaterials 2005, 26, 327-337.

25. Ong, J.L.; Chan, D.C. Hydroxyapatite and their use as coatings in dental implants: A review. Crit. Rev. Biomed. Eng. 2000, 28, 667-707.

26. Junker, R.; Dimakis, A.; Thoneick, M.; Jansen, J.A. Effects of implant surface coatings and composition on bone integration: A systematic review. Clin. Oral Implant. Res. 2009, 20, 185-206.

27. Wang, C.; Karlis, G.A.; Anderson, G.I.; Dunstan, C.R.; Carbone, A.; Berger, G.; Ploska, U.; Zreiqat, H. Bone growth is enhanced by novel bioceramic coatings on $\mathrm{Ti}$ alloy implants. J. Biomed. Mater. Res. Part A 2009, 90, 419-428.

28. Palmquist, A.; Omar, O.M.; Esposito, M.; Lausmaa, J.; Thomsen, P. Titanium oral implants: Surface characteristics, interface biology and clinical outcome. J. R. Soc. Interf. 2010, 7, S515-S527.

29. Dinda, G.P.; Shin, J.; Mazumder, J. Pulsed laser deposition of hydroxyapatite thin films on Ti-6Al-4V: Effect of heat treatment on structure and properties. Acta Biomater. 2009, 5, 1821-1830.

30. Suchanek, W.; Yoshimura, M. Processing and properties of hydroxyapatite-based biomaterials for use as hard tissue replacement implants. J. Mater. Res. 1998, 13, 94-117.

31. Paital, S.R.; Dahotre, N.B. Calcium phosphate coatings for bio-implant applications: Materials, performance factors, and methodologies. Mater. Sci. Eng. Rep. 2009, 66, 1-70.

32. Sima, L.E.; Stan, G.E.; Morosanu, C.O.; Melinescu, A.; Ianculescu, A.; Melinte, R.; Neamtu, J.; Petrescu, S.M. Differentiation of mesenchymal stem cells onto highly adherent radio frequency-sputtered carbonated hydroxylapatite thin films. J. Biomed. Mater. Res. 2010, 95, 1203-1214.

33. Saithna, A. The influence of hydroxyapatite coating of external fixator pins on pin loosening and pin track infection: A systematic review. Injury 2010, 41, 128-132.

34. Barrere, F.; van der Valk, C.M.; Meijer, G.; Dalmeijer, R.A.; de Groot, K.; Layrolle, P. Osteointegration of biomimetic apatite coating applied onto dense and porous metal implants in femurs of goats. J. Biomed. Mater. Res. Appl. Biomater. 2003, 67, 655-665.

35. Morris, H.F.; Ochi, S.; Spray, J.R.; Olson, J.W. Periodontal-type measurements associated with hydroxyapatite-coated and non-HA-coated implants: Uncovering to 36 months. Ann. Periodontol. 2000, 5, 56-67.

36. Dudek, A. Investigations of microstructure and properties in bioceramic coatings used in medicine. Arch. Metall. Mater. 2011, 56, 135-140.

37. Pichugin, V.F.; Surmenev, R.A.; Shesterikov, E.V.; Ryabtseva, M.A.; Eshenko, E.V.; Tverdokhlebov, S.I.; Prymak, O.; Epple, M. The preparation of calcium phosphate coatings on titanium and nickel-titanium by rf-magnetron-sputtered deposition: Composition, structure and micromechanical properties. Surf. Coatings Technol. 2008, 202, 3913-3920.

38. Surmenev, R.A.; Ryabtseva, M.A.; Shesterikov, E.V.; Pichugin, V.F.; Peitsch, T.; Epple, M. The release of nickel from nickel-titanium (NiTi) is strongly reduced by a sub-micrometer thin layer of calcium phosphate deposited by rf-magnetron sputtering. J. Mater. Sci. Mater. Med. 2010, 21, $1233-1239$. 
39. Cao, N.; Dong, J.; Wang, Q.; Ma, Q.; Wang, F.; Chen, H.; Xue, C.; Li, M. Plasma-sprayed hydroxyapatite coating on carbon/carbon composite scaffolds for bone tissue engineering and related tests in vivo. J. Biomed. Mater. Res. 2010, 92, 1019-1027.

40. Tang, Q.; Brooks, R.; Rushton, N.; Best, S. Production and characterization of HA and SiHA coatings. J. Mater. Sci. Mater. Med. 2010, 21, 173-181.

41. Cheng, G.J.; Ye, C. Experiment, thermal simulation, and characterizations on transmission laser coating of hydroxyapatite on metal implant. J. Biomed. Mater. Res. 2010, 92, 70-79.

42. Carrado, A. Structural, microstructural, and residual stress investigations of plasma-sprayed hydroxyapatite on Ti-6Al-4 V. ACS Appl. Mater. Interf. 2010, 2, 561-565.

43. Surmenev, R.A.; Surmeneva, M.A.; Evdokimov, K.E.; Pichugin, V.F.; Peitsch, T.; Epple, M. The influence of the deposition parameters on the properties of an rf-magnetron-deposited nanostructured calcium phosphate coating and a possible growth mechanism. Surf. Coatings Technol. 2011, 205, 3600-3606.

44. Wolke, J.G.C.; de Blieck-Hogervorst, J.M.A.; Dhert, W.J.A.; Klein, C.P.A.T.; de Groot, K. Studies on the thermal spraying of apatite bioceramics. J. Therm. Spray Technol. 1992, 1, 75-82.

45. Thian, E.S.; Huang, J.; Best, S.M.; Barber, Z.H.; Bonfield, W. Silicon-substituted hydroxyapatite thin films: Effect of annealing temperature on coating stability and bioactivity. J. Biomed. Mater. Res. 2006, 78, 121-128.

46. Porter, A.E.; Rea, S.M.; Galtrey, M.; Best, S.M.; Barber, Z.H. Production of thin film silicon-doped hydroxyapatite via sputter deposition. J. Mater. Sci. 2004, 39, 1895-1898.

47. Huang, T.; Xiao, Y.; Wang, S.; Huang, Y.; Liu, X.; Wu, F.; Gu, Z. Nanostructured Si, Mg, $\mathrm{CO}_{3}{ }^{2-}$ substituted hydroxyapatite coatings deposited by liquid precursor plasma spraying: Synthesis and characterization. J. Therm. Spray Technol. 2011, 20, 829-836.

48. Thian, E.S.; Huang, J.; Best, S.M.; Barber, Z.H.; Bonfield, W. Silicon-substituted hydroxyapatite: The next generation of bioactive coatings. Mater. Sci. Eng. 2007, 27, 251-256.

49. Xiao, F.J.; Peng, L.; Zhang, Y.; Yun, L.J. Silicon-substituted hydroxyapatite composite coating by using vacuum-plasma spraying and its interaction with human serum albumin. J. Mater. Sci. Mater. Med. 2009, 20, 1653-1658.

50. Gomes, P.S.; Botelho, C.; Lopes, M.A.; Santos, J.D.; Fernandes, M.H. Evaluation of human osteoblastic cell response to plasma-sprayed silicon-substituted hydroxyapatite coatings over titanium substrates. J. Biomed. Mater. Res. Appl. Biomater. 2010, 94, 337-346.

51. Gomes, P.; Botelho, C.; Lopes, M.; Santos, J.; Fernandes, M. Effect of silicon-containing hydroxyapatite coating on human in vitro osteoblastic response. Bone 2009, 44, s267.

52. Thian, E.S.; Best, S.M. Thin Calcium Phosphate Coatings for Medical Implants; SpringerVerlag: New York, NY, USA, 2009; p. 199.

53. Vestermark, M.T. Strontium in the bone-implant interface. Dan Med. Bull. 2011, 58, B4286.

54. Xue, W.; Hosick, H.L.; Bandyopadhyay, A.; Bose, S.; Ding, C.; Luk, K.D.K.; Cheung, K.M.C.; $\mathrm{Lu}$, W.W. Preparation and cell-materials interactions of plasma sprayed strontium-containing hydroxyapatite coating. Surf. Coatings Technol. 2007, 201, 4685-4693.

55. Mihailescu, I.N.; Ristoscu, C.; Bigi, A.; Mayer, I. Laser-Surface Interactions for New Materials Production. In Springer Series in Material Science; Springer: Berlin, Germany, 2010; Volume 130, pp. 235-260. 
56. Capuccini, C.; Torricelli, P.; Sima, F.; Boanini, E.; Ristoscu, C.; Bracci, B.; Socol, G.; Fini, M.; Mihailescu, I.N.; Bigi, A. Strontium-substituted hydroxyapatite coatings synthesized by pulsed-laser deposition: In vitro osteoblast and osteoclast response. Acta Biomater. 2008, 4, 1885-1893.

57. Bigi, A.; Boanini, E.; Capuccini, C.; Fini, M.; Mihailescu, I.N.; Ristoscu, C.; Sima, F.; Torricelli, P. Biofunctional alendronate-Hydroxyapatite thin films deposited by Matrix Assisted Pulsed Laser Evaporation. Biomaterials 2009, 30, 6168-6177.

58. Rau, J.V.; Generosi, A.; Laureti, S.; Komlev, V.S.; Ferro, D.; Cesaro, S.N.; Paci, B.; Albertini, V.R.; Agostinelli, E.; Barinov, S.M. Physicochemical investigation of pulsed laser deposited carbonated hydroxyapatite films on titanium. ACS Appl. Mater. Interf. 2009, 1, 1813-1820.

59. Ding, L.; Zheng, Y.; Wan, Q.B.; Pei, X.B.; Chen, S.Y. Fluoridated hydroxyapatite/carbon nanotubes composite coating fabricated by radio frequency magnetron sputtering. Mater. Sci. Forum 2011, 675-677, 869-871.

60. Rau, J.V.; Smirnov, V.V.; Laureti, S.; Generosi, A.; Varvaro, G.; Fosca, M.; Ferro, D.; Cesaro, S.N.; Albertini, V.R.; Barinov, S.M. Properties of pulsed laser deposited fluorinated hydroxyapatite films on titanium. Mater. Res. Bull. 2012 45, 1304-1310.

61. Yang, C.; Liu, F.; Ren, S.; Yang, G. Microstructure and magnetic properties of a two-phase alloy of $\alpha$-Fe and metastable $\mathrm{Fe}_{3}$ B. J. Magn. Magn. Mater. 2009, 321, 91-94.

62. Wang, G.; Zreiqat, H. Functional coatings or films for hard-tissue applications. Materials 2010, 3, 3994-4050.

63. Bai, X.; More, K.; Rouleau, C.M.; Rabiei, A. Functionally graded hydroxyapatite coatings doped with antibacterial components. Acta Biomater. 2010, 6, 2264-2273.

64. Simchi, A.; Tamjid, E.; Pishbin, F.; Boccaccini, A.R. Recent progress in inorganic and composite coatings with bactericidal capability for orthopaedic applications. Nanomed. Nanotechnol. Biol. Med. 2011, 7, 22-39.

65. Feng, Q.L.; Kim, T.N.; Wu, J.; Park, E.S.; Kim, J.O.; Lim, D.Y.; Cui, F.Z. Antibacterial effects of Ag-HAp thin films on alumina substrates. Thin Solid Films 1998, 335, 214-219.

66. Chen, Y.; Zheng, X.; Xie, Y.; Ji, H.; Ding, C.; Li, H.; Dai, K. Silver release from silver-containing hydroxyapatite coatings. Surf. Coatings Technol. 2010, 205, 1892-1896.

67. Shimazaki, T.; Miyamoto, H.; Ando, Y.; Noda, I.; Yonekura, Y.; Kawano, S.; Miyazaki, M.; Mawatari, M.; Hotokebuchi, T. In vivo antibacterial and silver-releasing properties of novel thermal sprayed silver-containing hydroxyapatite coating. J. Biomed. Mater. Res. Appl. Biomater. 2010, 92, 386-389.

68. De Jonge, L.T.; Leeuwenburgh, S.C.; Wolke, J.G.; Jansen, J.A. Organic-inorganic surface modifications for titanium implant surfaces. Pharm. Res. 2008, 25, 2357-2369.

69. Lynch, S.E.; Buser, D.; Hernandez, R.A.; Weber, H.P.; Stich, H.; Fox, C.H.; Williams, R.C. Effects of the platelet-derived growth factor/insulin-like growth factor-I combination on bone regeneration around titanium dental implants. Results of a pilot study in beagle dogs. J. Periodontol. 1991, 62, 710-716.

70. Sumner, D.R.; Turner, T.M.; Purchio, A.F.; Gombotz, W.R.; Urban, R.M.; Galante, J.O. Enhancement of bone ingrowth by transforming growth factor- $\beta$. J. Bone Jt. Surg. Ser. 1995, 77, 1135-1147. 
71. Puleo, D.A. Biochemical surface modification of Co-Cr-Mo. Biomaterials 1996, 17, 217-222.

72. Endo, K. Chemical modification of metallic implant surfaces with biofunctional proteins (Part 1). Molecular structure and biological activity of a modified NiTi alloy surface. Dent. Mater. J. 1995, 14, 185-198.

73. Nanci, A.; Wuest, J.D.; Peru, L.; Brunet, P.; Sharma, V.; Zalzal, S.; McKee, M.D. Chemical modification of titanium surfaces for covalent attachment of biological molecules. Can. Assoc. Radiol. J. 1998, 49, 324-335.

74. Schliephake, H.; Scharnweber, D. Chemical and biological functionalization of titanium for dental implants. J. Mater. Chem. 2008, 18, 2404-2414.

75. Nijhuis, A.W.G.; Leeuwenburgh, S.C.G.; Jansen, J.A. Wet-Chemical deposition of functional coatings for bone implantology. Macromol. Biosci. 2010, 10, 1316-1329.

76. Pierschbacher, M.D.; Ruoslahti, E. Cell attachment activity of fibronectin can be duplicated by small synthetic fragments of the molecule. Nature 1984, 309, 30-33.

77. Shin, H.; Jo, S.; Mikos, A.G. Biomimetic materials for tissue engineering. Biomaterials 2003, 24, 4353-4364.

78. Morra, M. Biochemical modification of titanium surfaces: Peptides and ECM proteins. Eur. Cell Mater. 2006, 12, 1-15.

79. Elmengaard, B.; Bechtold, J.E.; Soballe, K. In vivo effects of RGD-coated titanium implants inserted in two bone-gap models. J. Biomed. Mater. Res. 2005, 75, 249-255.

80. Schliephake, H.; Scharnweber, D.; Dard, M.; Sewing, A.; Aref, A.; Roessler, S. Functionalization of dental implant surfaces using adhesion molecules. J. Biomed. Mater. Res. Appl. Biomater. 2005, 73, 88-96.

81. Roessler, S.; Born, R.; Scharnweber, D.; Worch, H.; Sewing, A.; Dard, M. Biomimetic coatings functionalized with adhesion peptides for dental implants. J. Mater. Sci. Mater. Med. 2001, 12, 871-877.

82. Massia, S.P.; Hubbell, J.A. An RGD spacing of $440 \mathrm{~nm}$ is sufficient for integrin alpha V beta 3-mediated fibroblast spreading and $140 \mathrm{~nm}$ for focal contact and stress fiber formation. J. Cell Biol. 1991, 114, 1089-1100.

83. LeBaron, R.G.; Athanasiou, K.A. Extracellular matrix cell adhesion peptides: Functional applications in orthopedic materials. Tissue Eng. 2000, 6, 85-103.

84. Sreejalekshmi, K.G.; Nair, P.D. Biomimeticity in tissue engineering scaffolds through synthetic peptide modifications Altering chemistry for enhanced biological response. J. Biomed. Mater. Res. Part A 2010, 96, 477-491.

85. Solheim, E. Growth factors in bone. Int. Orthop. 1998, 22, 410-416.

86. Hall, J.; Sorensen, R.G.; Wozney, J.M.; Wikesjo, U.M. Bone formation at rhBMP-2-coated titanium implants in the rat ectopic model. J. Clin. Periodontol. 2007, 34, 444-451.

87. Siebers, M.C.; Walboomers, X.F.; Leewenburgh, S.C.; Wolke, J.C.; Boerman, O.C.; Jansen, J.A. Transforming growth factor-betal release from a porous electrostatic spray deposition-derived calcium phosphate coating. Tissue Eng. 2006, 12, 2449-2456.

88. De Jonge, L.T.; van den Beucken, J.J.J.P.; Leeuwenburgh, S.C.G.; Hamers, A.A.J.; Wolke, J.G.C.; Jansen, J.A. In vitro responses to electrosprayed alkaline phosphatase/calcium phosphate composite coatings. Acta Biomater. 2009, 5, 2773-2782. 
89. Anselme, K. Osteoblast adhesion on biomaterials. Biomaterials 2000, 21, 667-681.

90. Morra, M.; Cassinelli, C.; Cascardo, G.; Cahalan, P.; Cahalan, L.; Fini, M.; Giardino, R. Surface engineering of titanium by collagen immobilization. Surface characterization and in vitro and in vivo studies. Biomaterials 2003, 24, 4639-4654.

91. Schliephake, H.; Scharnweber, D.; Dard, M.; Robetaler, S.; Sewing, A.; Huttmann, C. Biological performance of biomimetic calcium phosphate coating of titanium implants in the dog mandible. J. Biomed. Mater. Res. 2003, 64, 225-234.

92. Wahl, D.A.; Czernuszka, J.T. Collagen-hydroxyapatite composites for hard tissue repair. Eur. Cell Mater. 2006, 11, 43-56.

93. De Jonge, L.T.; Leeuwenburgh, S.C.; van den Beucken, J.J.; te Riet, J.; Daamen, W.F.; Wolke, J.G.; Scharnweber, D.; Jansen, J.A. The osteogenic effect of electrosprayed nanoscale collagen/calcium phosphate coatings on titanium. Biomaterials 2010, 31, 2461-2469.

94. Fischer, U.; Hempel, U.; Becker, D.; Bierbaum, S.; Scharnweber, D.; Worch, H.; Wenzel, K.W. Transforming growth factor betal immobilized adsorptively on Ti6Al4V and collagen type I coated Ti6Al4V maintains its biological activity. Biomaterials 2003, 24, 2631-2641.

95. Cole, B.J.; Bostrom, M.P.; Pritchard, T.L.; Sumner, D.R.; Tomin, E.; Lane, J.M.; Weiland, A.J. Use of bone morphogenetic protein 2 on ectopic porous coated implants in the rat. Clin. Orthop. Relat. Res. 1997, 15, 219-228.

96. Herr, G.; Hartwig, C.H.; Boll, C.; Kusswetter, W. Ectopic bone formation by composites of BMP and metal implants in rats. Acta Orthop. Scand. 1996, 67, 606-610.

97. Liu, Y.; Hunziker, E.B.; Layrolle, P.; de Bruijn, J.D.; de Groot, K. Bone morphogenetic protein 2 incorporated into biomimetic coatings retains its biological activity. Tissue Eng. 2004, 10, 101-108.

98. Liu, Y.; Huse, R.O.; de Groot, K.; Buser, D.; Hunziker, E.B. Delivery mode and efficacy of BMP-2 in association with implants. J. Dent. Search 2007, 86, 84-89.

99. Liu, Y.; Hunziker, E.B.; Layrolle, P.; de Bruijn, J.D.; de Groot, K. Bone morphogenetic protein 2 incorporated into biomimetic coatings retains its biological activity. Tissue Eng. 2004, 10, 101-108.

100. Uludag, H.; Gao, T.; Porter, T.J.; Friess, W.; Wozney, J.M. Delivery systems for BMPs: Factors contributing to protein retention at an application site. J. Bone Jt. Surg. Am. 2001, 83, S128-S135.

101. Uludag, H.; D’Augusta, D.; Palmer, R.; Timony, G.; Wozney, J. Characterization of rhBMP-2 pharmacokinetics implanted with biomaterial carriers in the rat ectopic model. J. Biomed. Mater. Res. 1999, 46, 193-202.

102. Ewald, A.; Hösel, D.; Patel, S.; Grover, L.M.; Barralet, J.E.; Gbureck, U. Silver-doped calcium phosphate cements with antimicrobial activity. Acta Biomater. 2011, 7, 4064-4070.

103. Zhao, L.; Chu, P.K.; Zhang, Y.; Wu, Z. Antibacterial coatings on titanium implants. J. Biomed. Mater. Res. Appl. Biomater. 2009, 91, 470-480.

104. Jahoda, D.; Nyc, O.; Pokorny, D.; Landor, I.; Sosna, A. Antibiotic treatment for prevention of infectious complications in joint replacement. Acta Chir. Orthop. Traumatol. Cech. 2006, 73, $108-114$.

105. Alt, V.; Bitschnau, A.; Osterling, J.; Sewing, A.; Meyer, C.; Kraus, R.; Meissner, S.A.; Wenisch, S.; Domann, E.; Schnettler, R. The effects of combined gentamicin-hydroxyapatite coating for cementless joint prostheses on the reduction of infection rates in a rabbit infection prophylaxis model. Biomaterials 2006, 27, 4627-4634. 
106. Campbell, A.A.; Song, L.; Li, X.S.; Nelson, B.J.; Bottoni, C.; Brooks, D.E.; DeJong, E.S. Development, characterization, and anti-microbial efficacy of hydroxyapatite-chlorhexidine coatings produced by surface-induced mineralization. J. Biomed. Mater. Res. 2000, 53, 400-407.

107. Morra, M.; Cassinelli, C.; Cascardo, G.; Carpi, A.; Fini, M.; Giavaresi, G.; Giardino, R. Adsorption of cationic antibacterial on collagen-coated titanium implant devices. Biomed. Pharmacother. 2004, 58, 418-422.

108. Kim, W.-H.; Lee, S.-B.; Oh, K.-T.; Moon, S.-K.; Kim, K.-M.; Kim, K.-N. The release behavior of CHX from polymer-coated titanium surfaces. Surf. Interf. Anal. 2008, 40, 202-204.

109. Harris, L.G.; Mead, L.; Muller-Oberlander, E.; Richards, R.G. Bacteria and cell cytocompatibility studies on coated medical grade titanium surfaces. J. Biomed. Mater. Res. 2006, 78, 50-58.

110. Kozlovsky, A.; Artzi, Z.; Moses, O.; Kamin-Belsky, N.; Greenstein, R.B. Interaction of chlorhexidine with smooth and rough types of titanium surfaces. J. Periodontol. 2006, 77, 1194-1200.

111. Barbour, M.E.; O’Sullivan, D.J.; Jagger, D.C. Chlorhexidine adsorption to anatase and rutile titanium dioxide. Coll. Surf. Physicochem. Eng. Asp. 2007, 307, 116-120.

112. Darouiche, R.O.; Green, G.; Mansouri, M.D. Antimicrobial activity of antiseptic-coated orthopaedic devices. Int. J. Antimicrob. Agents 1998, 10, 83-86.

113. Jonathan, P.; Nazhat, S.N.; Blaker, J.J.; Boccaccini, A.R. In Vitro Attachment of Staphylococcus Epidermidis to Surgical Sutures with and without Ag-Containing Bioactive Glass Coating; Sage: London, UK, 2004; Volume 19, p. 11.

114. Roy, M.; Bandyopadhyay, A.; Bose, S. In vitro antimicrobial and biological properties of laser assisted tricalcium phosphate coating on titanium for load bearing implant. Mater. Sci. Eng. 2009, 29, 1965-1968.

115. Roelofs, A.J.; Thompson, K.; Gordon, S.; Rogers, M.J. Molecular mechanisms of action of bisphosphonates: Current status. Clin. Cancer Res. 2006, 12, 6222s-6230s.

116. Van beek, E.; Lowik, C.; van der Pluijm, G.; Papapoulos, S. The role of geranylgeranylation in bone resorption and its suppression by bisphosphonates in fetal bone explants in vitro: A clue to the mechanism of action of nitrogen-containing bisphosphonates. J. Bone Miner. Res. 1999, 14, $722-729$.

117. Wysowski, D.K. Reports of esophageal cancer with oral bisphosphonate use. Mass. Med. Soc. 2009, 360, 89-90.

118. Marx, R.E. Oral and intravenous bisphosphonate-induced osteonecrosis of the jaws. J. Oral Maxillofac. Surg. 2007, 65, 2397-2410.

119. Denissen, H.; van Beek, E.; Lowik, C.; Papapoulos, S.; van Den Hooff, A. Ceramic hydroxyapatite implants for the release of bisphosphonate. Bone Miner. 1994, 25, 123-134.

120. Seshima, H.; Yoshinari, M.; Takemoto, S.; Hattori, M.; Kawada, E.; Inoue, T.; Oda, Y. Control of bisphosphonate release using hydroxyapatite granules. J. Biomed. Mater. Res. Appl. Biomater. 2006, 78, 215-221.

121. Boanini, E.; Torricelli, P.; Gazzano, M.; Giardino, R.; Bigi, A. Alendronate-hydroxyapatite nanocomposites and their interaction with osteoclasts and osteoblast-like cells. Biomaterials 2008, 29, 790-796. 
122. Peter, B.; Pioletti, D.P.; Laib, S.; Bujoli, B.; Pilet, P.; Janvier, P.; Guicheux, J.; Zambelli, P.Y.; Bouler, J.M.; Gauthier, O. Calcium phosphate drug delivery system: Influence of local zoledronate release on bone implant osteointegration. Bone 2005, 36, 52-60.

123. Yang, Y.; Kim, K.-H.; Ong, J.L. A review on calcium phosphate coatings produced using a sputtering process an alternative to plasma spraying. Biomaterials 2005, 26, 327-337.

124. Huang, Y.; Qu, Y.; Yang, B.; Li, W.; Zhang, B.; Zhang, X. In vivo biological responses of plasma sprayed hydroxyapatite coatings with an electric polarized treatment in alkaline solution. Mater. Sci. Eng. 2009, 29, 2411-2416.

125. Wu, G.M.; Hsiao, W.D.; Kung, S.F. Investigation of hydroxyapatite coated polyether ether ketone composites by gas plasma sprays. Surf. Coatings Technol. 2009, 203, 2755-2758.

126. Kozerski, S.; Pawlowski, L.; Jaworski, R.; Roudet, F.; Petit, F. Two zones microstructure of suspension plasma sprayed hydroxyapatite coatings. Surf. Coatings Technol. 2010, 204, 1380-1387.

127. D’Haese, R.; Pawlowski, L.; Bigan, M.; Jaworski, R.; Martel, M. Phase evolution of hydroxapatite coatings suspension plasma sprayed using variable parameters in simulated body fluid. Surf. Coatings Technol. 2010, 204, 1236-1246.

128. Cao, N.; Dong, J.; Wang, Q.; Ma, Q.; Xue, C.; Li, M. An experimental bone defect healing with hydroxyapatite coating plasma sprayed on carbon/carbon composite implants. Surf. Coatings Technol. 2010, 205, 1150-1156.

129. Noda, I.; Miyaji, F.; Ando, Y.; Miyamoto, H.; Shimazaki, T.; Yonekura, Y.; Miyazaki, M.; Mawatari, M.; Hotokebuchi, T. Development of novel thermal sprayed antibacterial coating and evaluation of release properties of silver ions. J. Biomed. Mater. Res. Appl. Biomater. 2009, 89, 456-465.

130. Hong, Z.; Mello, A.; Yoshida, T.; Luan, L.; Stern, P.H.; Rossi, A.; Ellis, D.E.; Ketterson, J.B. Osteoblast proliferation on hydroxyapatite coated substrates prepared by right angle magnetron sputtering. J. Biomed. Mater. Res. 2010, 93, 878-885.

131. Jelinek, M.; Weiserova, M.; Kocourek, T.; Zezulova, M.; Strnad, J. Biomedical properties of laser prepared silver-doped hydroxyapatite. Laser Phys. 2011, 21, 1265-1269.

132. Jelinek, M.; Kocourek, T.; Jurek, K.; Remsa, J.; Mikšovský, J.; Weiserova, M.; Strnad, J.; Luxbacher, T. Antibacterial properties of Ag-doped hydroxyapatite layers prepared by PLD method. Appl. Phys. Mater. Sci. Proc. 2010, 101, 615-620.

133. Koch, C.F.; Johnson, S.; Kumar, D.; Jelinek, M.; Chrisey, D.B.; Doraiswamy, A.; Jin, C.; Narayan, R.J.; Mihailescu, I.N. Pulsed laser deposition of hydroxyapatite thin films. Mater. Sci. Eng. 2007, 27, 484-494.

134. Vasanthan, A.; Kim, H.; Drukteinis, S.; Lacefield, W. Implant surface modification using laser guided coatings: In vitro comparison of mechanical properties. J. Prosthodont. 2008, 17, 357-364.

135. Man, H.C.; Chiu, K.Y.; Cheng, F.T.; Wong, K.H. Adhesion study of pulsed laser deposited hydroxyapatite coating on laser surface nitrided titanium. Thin Solid Films 2009, 517, 5496-5501.

136. Yang, S.; Xing, W.; Man, H.C. Pulsed laser deposition of hydroxyapatite film on laser gas nitriding NiTi substrate. Appl. Surf. Sci. 2009, 255, 9889-9892. 
137. Socol, G.; Macovei, A.M.; Miroiu, F.; Stefan, N.; Duta, L.; Dorcioman, G.; Mihailescu, I.N.; Petrescu, S.M.; Stan, G.E.; Marcov, D.A.; et al. Hydroxyapatite thin films synthesized by pulsed laser deposition and magnetron sputtering on PMMA substrates for medical applications. Mater. Sci. Eng. Solid-State Mater. Adv. Technol. 2010, 169, 159-168.

138. Rajesh, P.; Muraleedharan, C.V.; Komath, M.; Varma, H. Pulsed laser deposition of hydroxyapatite on titanium substrate with titania interlayer. J. Mater. Sci. Mater. Med. 2011, 22, 497-505.

139. Zeng, H.; Lacefield, W.R.; Mirov, S. Structural and morphological study of pulsed laser deposited calcium phosphate bioceramic coatings: Influence of deposition conditions, laser parameters, and target properties. J. Biomed. Mater. Res. 2000, 50, 248-258.

140. Garcia-Sanz, F.J.; Mayor, M.B.; Arias, J.L.; Pou, J.; Lean, B.; Perez-Amor, M. Hydroxyapatite coatings: A comparative study between plasma-spray and pulsed laser deposition techniques. J. Mater. Sci. Mater. Med. 1997, 8, 861-865.

141. Choi, J.M.; Kim, H.E.; Lee, I.S. Ion-beam-assisted deposition (IBAD) of hydroxyapatite coating layer on Ti-based metal substrate. Biomaterials 2000, 21, 469-473.

142. Luo, Z.S.; Cui, F.Z.; Feng, Q.L.; Li, H.D.; Zhu, X.D.; Spector, M. In vitro and in vivo evaluation of degradability of hydroxyapatite coatings synthesized by ion beam-assisted deposition. Surf. Coatings Technol. 2000, 131, 192-195.

143. Kim, T.N.; Feng, Q.L.; Luo, Z.S.; Cui, F.Z.; Kim, J.O. Highly adhesive hydroxyapatite coatings on alumina substrates prepared by ion-beam assisted deposition. Surf. Coatings Technol. 1998, 99, 20-23.

144. Coelho, P.G.; Lemons, J.E. Physico/chemical characterization and in vivo evaluation of nanothickness bioceramic depositions on alumina-blasted/acid-etched Ti-6Al-4V implant surfaces. J. Biomed. Mater. Res. 2009, 90, 351-361.

145. Rabiei, A.; Thomas, B.; Jin, C.; Narayan, R.; Cuomo, J.; Yang, Y.; Ong, J.L. A study on functionally graded HA coatings processed using ion beam assisted deposition with in situ heat treatment. Surf. Coatings Technol. 2006, 200, 6111-6116.

146. Coelho, P.G.; Cardaropoli, G.; Suzuki, M.; Lemons, J.E. Histomorphometric evaluation of a nanothickness bioceramic deposition on endosseous implants: A study in dogs. Clin. Implant Dent. Relat. Res. 2009, 11, 292-302.

147. Kim, H.; Choi, S.H.; Chung, S.M.; Li, L.H.; Lee, I.S. Enhanced bone forming ability of SLA-treated Ti coated with a calcium phosphate thin film formed by e-beam evaporation. Biomed. Mater. 2009, 5, 044106.

148. Lee, I.S.; Whang, C.N.; Kim, H.E.; Park, J.C.; Song, J.H.; Kim, S.R. Various Ca/P ratios of thin calcium phosphate films. Mater. Sci. Eng. 2002, 22, 15-20.

149. Rautray, T.R.; Narayanan, R.; Kwon, T.Y.; Kim, K.H. Surface modification of titanium and titanium alloys by ion implantation. J. Biomed. Mater. Res. Appl. Biomater. 2011, 93, 581-591.

150. Yang, J.X.; Jiao, Y.P.; Cui, F.Z.; Lee, I.S.; Yin, Q.S.; Zhang, Y. Modification of degradation behavior of magnesium alloy by IBAD coating of calcium phosphate. Surf. Coatings Technol. 2008, 202, 5733-5736.

151. Krout, A.; Wen, H.B.; Hippensteel, E.; Li, P. A hybrid coating of biomimetic apatite and osteocalcin. J. Biomed. Mater. Res. 2005, 73, 377-387. 
152. Chen, C.; Lee, I.-S.; Zhang, S.-M.; Yang, H.C. Biomimetic apatite formation on calcium phosphate-coated titanium in Dulbecco's phosphate-buffered saline solution containing $\mathrm{CaCl}_{2}$ with and without fibronectin. Acta Biomater. 2010, 6, 2274-2281.

153. Ryu, H.S.; Hong, S.-H. Hybrid coatings of poly(L-lysine) and apatite on micro-arc oxidized titania. Mater. Lett. 2009, 63, 2107-2110.

154. Liu, Y.; de Groot, K.; Hunziker, E.B. BMP-2 liberated from biomimetic implant coatings induces and sustains direct ossification in an ectopic rat model. Bone 2005, 36, 745-757.

155. Ishibe, T.; Goto, T.; Kodama, T.; Miyazaki, T.; Kobayashi, S.; Takahashi, T. Bone formation on apatite-coated titanium with incorporated BMP-2/heparin in vivo. Oral Surg. Oral Med. Oral Pathol. Oral Radiol. Endod. 2009, 108, 867-875.

156. Leivo, J.; Meretoja, V.; Vippola, M.; Levanen, E.; Vallittu, P.; Mantyla, T.A. Sol-gel derived aluminosilicate coatings on alumina as substrate for osteoblasts. Acta Biomater. 2006, 2, 659-668.

157. Cheng, K.; Weng, W.; Wang, H.; Zhang, S. In vitro behavior of osteoblast-like cells on fluoridated hydroxyapatite coatings. Biomaterials 2005, 26, 6288-6295.

158. Balamurugan, A.; Rebelo, A.H.S.; Lemos, A.F.; Rocha, J.H.G.; Ventura, J.M.G.; Ferreira, J.M.F. Suitability evaluation of sol-gel derived Si-substituted hydroxyapatite for dental and maxillofacial applications through in vitro osteoblasts response. Dent. Mater. 2008, 24, 1374-1380.

159. Liu, J.; Miao, X. Sol-gel derived bioglass as a coating material for porous alumina scaffolds. Ceram. Int. 2004, 30, 1781-1785.

160. Fathi, M.H.; Doost Mohammadi, A. Preparation and characterization of sol-gel bioactive glass coating for improvement of biocompatibility of human body implant. Mater. Sci. Eng. 2008, 474, $128-133$.

161. Mirhosseini, N.; Crouse, P.L.; Li, L.; Garrod, D. Combined laser/sol-gel synthesis of calcium silicate coating on Ti6Al4V substrates for improved cell integration. Appl. Surf. Sci. 2007, 253, 7998-8002.

162. Pang, X.; Casagrande, T.; Zhitomirsky, I. Electrophoretic deposition of hydroxyapatite-CaSiO 3 -chitosan composite coatings. J. Coll. Interf. Sci. 2009, 330, 323-329.

163. Sun, F.; Pang, X.; Zhitomirsky, I. Electrophoretic deposition of composite hydroxyapatite-chitosan-heparin coatings. J. Mater. Proc. Technol. 2009, 209, 1597-1606.

164. Grandfield, K.; Zhitomirsky, I. Electrophoretic deposition of composite hydroxyapatite-silica-chitosan coatings. Mater. Charact. 2008, 59, 61-67.

165. Schouten, C.; Meijer, G.J.; van den Beucken, J.J.J.P.; Leeuwenburgh, S.C.G.; de Jonge, L.T.; Wolke, J.G.C.; Spauwen, P.H.M.; Jansen, J.A. In vivo bone response and mechanical evaluation of electrosprayed $\mathrm{CaP}$ nanoparticle coatings using the iliac crest of goats as an implantation model. Acta Biomater. 2010, 6, 2227-2236.

166. Leeuwenburgh, S.C.G.; Wolke, J.G.C.; Siebers, M.C.; Schoonman, J.; Jansen, J.A. In vitro and in vivo reactivity of porous, electrosprayed calcium phosphate coatings. Biomaterials 2006, 27, 3368-3378.

167. Iafisco, M.; Bosco, R.; Leeuwenburgh, S.C.G.; van den Beucken, J.J.J.P.; Jansen, J.A.; Prat, M.; Roveri, N. Electrostatic spray deposition of biomimetic nanocrystalline apatite coatings onto titanium. Adv. Eng. Mater. 2012, 14, B13-B20. 
168. De Jonge, L.T.; Leeuwenburgh, S.C.G.; van den Beucken, J.J.J.P.; Wolke, J.G.C.; Jansen, J.A. Electrosprayed enzyme coatings as bioinspired alternatives to bioceramic coatings for orthopedic and oral implants. Adv. Funct. Mater. 2009, 19, 755-762.

169. Alghamdi, H.S.; van Oirschot, B.; Bosco, R.; den Beucken, J.J.J.P.; Aldosari, A.A.F.; Anil, S.; Jansen, J.A. Biological response to titanium implants coated with nanocrystals calcium phosphate or type 1 collagen in a dog model. Clin. Oral Implant. Res. 2012, doi:10.1111/j.16000501.2011.02409.x.

170. Gross, K.A.; Saber-Samandari, S. Revealing mechanical properties of a suspension plasma sprayed coating with nanoindentation. Surf. Coatings Technol. 2009, 203, 2995-2999.

171. Huang, Y.; Song, L.; Liu, X.; Xiao, Y.; Wu, Y.; Chen, J.; Wu, F.; Gu, Z. Hydroxyapatite coatings deposited by liquid precursor plasma spraying: Controlled dense and porous microstructures and osteoblastic cell responses. Biofabrication 2010, 2, 045003.

172. Sobieszczyk, S.; Zielinski, A. Coatings in arthroplasty. Adv. Mater. Sci. 2008, 8, 35-54.

173. Khor, K.A.; Li, H.; Cheang, P. Significance of melt-fraction in HVOF sprayed hydroxyapatite particles, splats and coatings. Biomaterials 2004, 25, 1177-1186.

174. Morks, M.F.; Fahim, N.F.; Kobayashi, A. Structure, mechanical performance and electrochemical characterization of plasma sprayed $\mathrm{SiO}_{2} /$ Ti-reinforced hydroxyapatite biomedical coatings. Appl. Surf. Sci. 2008, 255, 3426-3433.

175. Hasan, S.; Stokes, J. Design of experiment analysis of the Sulzer Metco DJ high velocity oxy-fuel coating of hydroxyapatite for orthopedic applications. J. Therm. Spray Technol. 2010, 20, 186-194.

176. Morks, M.F. Fabrication and characterization of plasma-sprayed $\mathrm{HA} / \mathrm{SiO}_{2}$ coatings for biomedical application. J. Mech. Behav. Biomed. Mater. 2008, 1, 105-111.

177. Morks, M.F.; Kobayashi, A.; Fahim, N.F. Abrasive wear behavior of sprayed hydroxyapitite coatings by gas tunnel type plasma spraying. Wear 2007, 262, 204-209.

178. Heimann, R.B. Thermal spraying of biomaterials. Surf. Coatings Technol. 2006, 201, 2012-2019.

179. Lima, R.S.; Dimitrievska, S.; Bureau, M.N.; Marple, B.R.; Petit, A.; Mwale, F.; Antoniou, J.

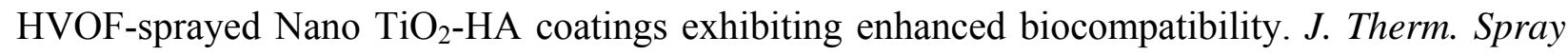
Technol. 2010, 19, 336-343.

180. Yamashita, K.; Arashi, T.; Kitagaki, K.; Yamada, S.; Umegaki, T.; Ogawa, K. Preparation of apatite thin films through rf-sputtering from calcium phosphate glasses. J. Am. Ceram. Soc. 1994, 77, 2401-2407.

181. Van Der Wal, E.; Oldenburg, S.J.; Heij, T.; Denier van Der Gon, A.W.; Brongersma, H.H.; Wolke, J.G.C.; Jansen, J.A.; Vredenberg, A.M. Adsorption and desorption of Ca and $\mathrm{PO}_{4}$ species from SBFs on RF-sputtered calcium phosphate thin films. Appl. Surf. Sci. 2006, 252, 3843-3854.

182. Jansen, J.A.; Wolke, J.G.C.; Swann, S.; van Der Waerden, J.P.C.M.; de Groof, K. Application of magnetron sputtering for producing ceramic coatings on implant materials. Clin. Oral Implants Res. 1993, 4, 28-34.

183. Van Dijk, K.; Schaeken, H.G.; Wolke, J.G.C.; Jansen, J.A. Influence of annealing temperature on RF magnetron sputtered calcium phosphate coatings. Biomaterials 1996, 17, 405-410. 
184. Van Dijk, K.; Schaeken, H.G.; Wolke, J.C.G.; Maree, C.H.M.; Habraken, F.H.P.M.; Verhoeven, J.; Jansen, J.A. Influence of discharge power level on the properties of hydroxyapatite films deposited on Ti6A14V with RF magnetron sputtering. J. Biomed. Mater. Res. 1995, 29, 269-276.

185. Yang, J.; Cui, F.Z.; Lee, I.S.; Wang, X. Plasma surface modification of magnesium alloy for biomedical application. Surf. Coatings Technol. 2010, 205, S182-S187.

186. Cotell, C.M.; Chrisey, D.B.; Grabowski, K.S.; Sprague, J.A.; Gossett, C.R. Pulsed laser deposition of hydroxylapatite thin films on Ti-6Al-4V. J. Appl. Biomater. 1992, 3, 87-93.

187. Leon, B. Pulsed Laser Deposition of Thin Calcium Phosphate Coatings; Springer: New York, NY, USA, 2009; p. 101.

188. Jedynski, M.; Hoffman, J.; Mroz, W.; Szymanski, Z. Plasma plume induced during ArF laser ablation of hydroxyapatite. Appl. Surf. Sci. 2008, 255, 2230-2236.

189. Jelinek, M.; Weiserova, M.; Kocourek, T.; Zezulova, M.; Strnad, J. Biomedical properties of laser prepared silver-doped hydroxyapatite. Laser Phys. 2011, 21, 1265-1269.

190. Mroz, V. Functional properties of nanostructured materials. NATO Sci. Ser. 2006, 223, 183-196.

191. Johnson, S.; Haluska, M.; Narayan, R.J.; Snyder, R.L. In situ annealing of hydroxyapatite thin films. Mater. Sci. Eng. 2006, 26, 1312-1316.

192. Junker, R.; Dimakis, A.; Thoneick, M.; Jansen, J.A. Effects of implant surface coatings and composition on bone integration: A systematic review. Clin. Oral Implants Res. 2009, 20, 185-206.

193. Roy, M.; Bandyopadhyay, A.; Bose, S. Induction plasma sprayed nano hydroxyapatite coatings on titanium for orthopaedic and dental implants. Surf. Coatings Technol. 2011, 205, 2785-2792.

194. Liu, X.; Chu, P.K.; Ding, C. Surface nano-functionalization of biomaterials. Mater. Sci. Eng. Rep. 2011, 70, 275-302.

195. Kokubo, T.; Takadama, H. How useful is SBF in predicting in vivo bone bioactivity? Biomaterials 2006, 27, 2907-2915.

196. Hench, L.L.; West, J.K. The sol-gel process. Chem. Rev. 1990, 90, 33-72.

197. Paital, S.R.; Dahotre, N.B. Calcium phosphate coatings for bio-implant applications: Materials, performance factors, and methodologies. Mater. Sci. Eng. Rep. 2009, 66, 1-70.

198. Kwok, C.T.; Wong, P.K.; Cheng, F.T.; Man, H.C. Characterization and corrosion behavior of hydroxyapatite coatings on Ti6A14V fabricated by electrophoretic deposition. Appl. Surf. Sci. 2009, 255, 6736-6744.

199. Stoch, A.; Brożek, A.; Kmita, G.; Stoch, J.; Jastrzębski, W.; Rakowska, A. Electrophoretic coating of hydroxyapatite on titanium implants. J. Mol. Struct. 2001, 596, 191-200.

200. Siefert, W. Corona spray pyrolysis: A new coating technique with an extremely enhanced deposition efficiency. Thin Solid Films 1984, 120, 267-274.

201. Wilhelm, O.; Mädler, L.; Pratsinis, S.E. Electrospray evaporation and deposition. J. Aerosol. Sci. 2003, 34, 815-836.

(C) 2012 by the authors; licensee MDPI, Basel, Switzerland. This article is an open access article distributed under the terms and conditions of the Creative Commons Attribution license (http://creativecommons.org/licenses/by/3.0/). 